\title{
Studi Eksperimen Kehilangan Energi Pada Sistem Pelimpah Dengan Kemiringan 1: 1 Akibat Penurunan Dasar Kolam Olak
}

\author{
Rolanda Noverdo $^{1 *}$, Very Dermawan ${ }^{1}$, Dian Sisinggih $^{1}$ \\ ${ }^{1}$ Jurusan Teknik Pengairan Universitas Brawijaya, \\ Jalan MT. Haryono No. 167, Kota Malang, 65145, INDONESIA \\ *rolandanoverdo@student.ub.ac.id
}

\begin{abstract}
The structural integrity of a structure in a construction is very important. In a weir, an energy dissipator is an important part in the spillway system which is useful for reducing the energy that occurs due to hydraulic jump affected by high flow velocity. High flow velocity produces high energy with a large destructive force causes scouring at the bottom of the channel and results in disruption of the structural integrity of the weir. To keep the hydraulic jump close to the spillway and stilling basin, it is necessary to lower the base of stilling basin. This study aims to determine the hydraulic condition of lowering the base of stilling basin and to determine the condition of energy dissipation of lowering the base of stilling basin. This study is useful as an alternative for designing and planning energy dissipator in the spillway system. To determine the efficiency of energy dissipation, experiment was carried out by conducting several alternatives, Original Series, Series I, Series II, Series III, Series IV, Series V and with several discharge flow experiments. Series V is the most efficient of energy dissipation among all experimental alternatives.
\end{abstract}

Keywords: Energy Dissipation, Hydraulic, Scouring, Spillway System, Stilling Basin

\begin{abstract}
Abstrak: Keutuhan struktur bangunan pada suatu konstruksi adalah hal yang sangat penting. Pada bendung, peredam energi merupakan bangunan penting pada sistem pelimpah yang berguna untuk meredam energi yang terjadi akibat loncatan air yang dipengaruhi oleh kecepatan aliran yang tinggi. Kecepatan aliran yang tinggi menghasilkan energi yang tinggi dengan daya rusak yang besar yang menyebabkan penggerusan pada dasar kolam olak dan mengakibatkan terganggunya keutuhan struktur bangunan bendung. Untuk menjaga agar loncatan air tetap dekat dengan sistem pelimpah dan kolam olak, maka perlu dilakukan penurunan dasar kolam olak. Studi ini bertujuan untuk mengetahui kondisi aliran sebelum dan sesudah penurunan dasar kolam olak dan untuk mengetahui kondisi
\end{abstract}


peredaman energi sebelum dan sesudah penurunan dasar kolam olak. Studi ini bermanfaat sebagai alternatif perencanaan dan pemilihan peredam energi pada sistem pelimpah bendung. Dalam upaya mendapatkan nilai efisiensi peredaman energi terbaik, penelitian dilakukan dengan melakukan beberapa alternatif penelitian, mulai dari Seri Original, Seri I, Seri II, Seri III, Seri IV dan Seri V dan dengan beberapa percobaan aliran debit. Seri V adalah alternatif penelitian terbaik sebab memberikan nilai efisiensi peredaman energi terbaik di antara semua alternatif penelitian.

Kata kunci: Hidrolika, Kolam Olak, Penggerusan, Peredaman Energi, Sistem Pelimpah

\section{Pendahuluan}

Bendung adalah suatu konstruksi bangunan air melintang pada aliran sungai yang memiliki fungsi untuk meninggikan muka air yang kemudian dialirkan ke arah tepi kiri dan tepi kanan sungai untuk selanjutnya mengalir ke dalam saluran melalui sebuah bangunan pengambilan jaringan irigasi. Ada banyak faktor yang harus diperhatikan dalam merencanakan sebuah bendung antara lain kecepatan air $(\mathrm{V})$, debit air $(\mathrm{Q})$, tinggi muka sawah, morfologi sungai dan posisi konstruksi bendung terhadap garis alur sungai. Perencanaan yang baik tentu dilaksanakan untuk tercapainya tujuan awal perencanaan pembangunan bendung yaitu untuk memenuhi kebutuhan air dengan memaksimalkan air mengalir pada sungai, selain itu perencanaan yang baik dilakukan guna mengatasi masalahmasalah yang akan timbul akibat perencanaan itu sendiri. Masalah yang sering timbul adalah penggerusan di hilir bendung akibat aliran air yang tinggi. Oleh sebab itu, diperlukan suatu perlakuan yang dapat mengatasi terjadinya gerusan di hilir bendung, yaitu dengan pembangunan bangunan peredam energi.

Bangunan peredam energi yang umum digunakan adalah kolam olakan (stilling basin) yang di bangun guna mengatasi gerusan di hilir bendung yang dapat mengurangi atau meredam energi yang dihasilkan akibat adanya kecepatan aliran air yang tinggi yang mengalir dari mercu bendung. Untuk merencanakan pembangunan kolam olak, terlebih dahulu dapat dilakukan pemodelan di laboratorium. Pemodelan ini sekaligus sebagai simulasi dan percobaan terhadap penerapan data-data yang telah dikumpulkan yang kemudian diujicobakan untuk mendapatkan hasil kelayakan dan efisisensi kolam olak tersebut sebagai bangunan peredam energi.

Berdasarkan hasil uji coba dan penerapan bangunan peredam energi, peredam energi kolam olak masih seringkali mengalami masalah yang menyebabkan terjadinya gerusan air di bagian hilir kolam olak. Untuk menangani masalah tersebut, dilakukan percobaan perubahan penurunan setiap $5 \mathrm{~cm}$ pada dasar kolam olak datar dengan kemiringan peluncur 1:1. Dengan percobaan perubahan penurunan dasar kolam olak ini diharapkan mampu mengatasi permasalahan gerusan yang terjadi akibat energi yang dihasilkan oleh kecepatan air mengalir dari mercu sehingga dalam hal ini fungsi kolam olak sebagai peredam energi mampu bekerja secara maksimal dan efisien.

Studi ini bertujuan untuk mengetahui kondisi aliran sebelum dan sesudah penurunan dasar kolam olak dan untuk mengetahui kondisi peredaman energi sebelum dan sesudah penurunan dasar kolam olak. 


\section{Bahan dan Metode}

\subsection{Bahan}

Penelitian dilakukan dengan melakukan penurunan dasar kolam olak. Untuk mendapatkan perbandingan hasil penelitian maka eksperimen dilakukan pada lima seri penurunan dari Seri Original yaitu Seri I, Seri II, Seri III, Seri IV, dan Seri V dengan beberapa aliran debit yang berbeda. Pengumpulan data dalam studi dilakukan di Laboratorium Sungai dan Rawa Teknik Pengairan Universitas Brawijaya dari hasil uji pemodelan penurunan dasar kolam olak datar. Data-data tersebut yaitu:

1. Kedalaman kritis

2. Kecepatan kritis

3. Kedalaman aliran di hilir kaki pelimpah

4. Kecepatan aliran di hilir kaki pelimpah

5. Kedalaman aliran setelah loncatan hidraulik

6. Kecepatan aliran setelah loncatan hidraulik

7. Panjang loncatan aliran

\subsection{Metode}

Prosedur penelitian diilustrasikan dalam diagram alir penelitian berikut:

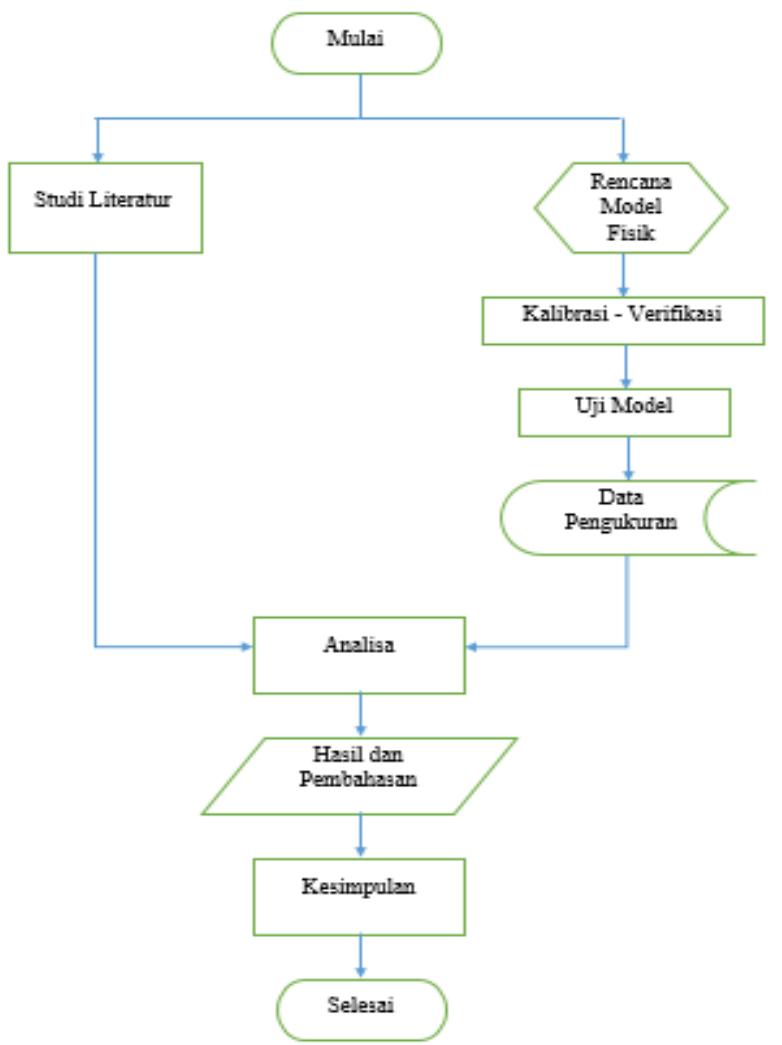

Gambar 1. Diagram alir penelitian

Studi literatur dan rencana model fisik adalah tahap pengumpulan teori dan perencanaan eksperimen model fisik. Kalibrasi dilakukan untuk pengecekan dan pengaturan akurasi dari alat ukur dengan cara membandingkannya dengan tolak ukur yang berstandar. Uji model adalah proses eksperimen atau pengujian model fisik sehingga 
didapat data uji model fisik. Data tersebut diolah ke dalam berbagai perhitungan, yaitu perhitungan hubungan efisiensi peredaman energi dan debit pada tinggi jatuh yang sama dengan kemiringan $1: 1$ pada saluran peluncur dan perhitungan hubungan efisiensi peredaman energi dan tinggi jatuh pada debit yang sama dengan kemiringan $1: 1$ pada saluran peluncur. Perhitungan dilakukan terhadap setiap seri penurunan dasar kolam olak datar. Setelah dilakukan pengolahan data, selanjutnya hasil perhitungan dianalisa dengan melakukan perbandingan terhadap setiap seri penurunan dasar kolam olak sehingga didapat hasil efisiensi peredaman energi terbaik.

\section{Hasil dan Pembahasan}

Penelitian dilakukan dengan melakukan dua macam penurunan kolam olak datar yaitu penurunan saluran datar dan penurunan dasar kolam olak datar. Masing-masing penurunan mendapatkan perlakuan tinggi penurunan yang sama yang ditampilkan pada ilustrasi di bawah ini:

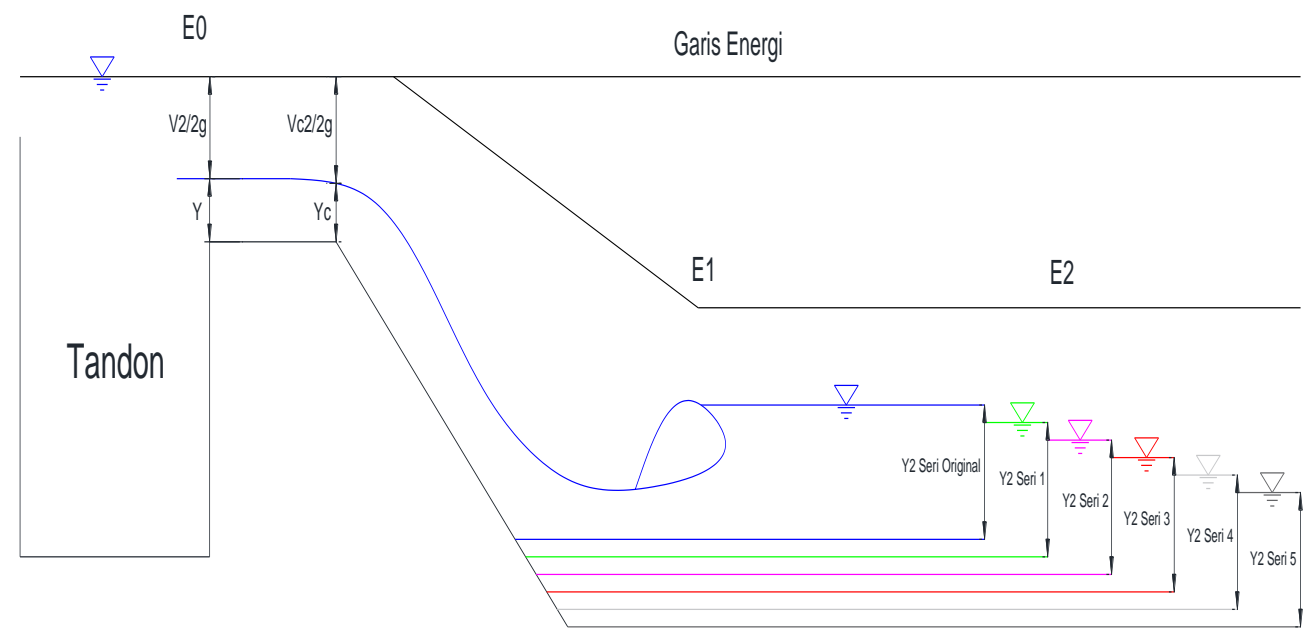

Gambar 2. Ilustrasi penurunan saluran datar

Ilustrasi penurunan saluran datar di atas didapatkan melalui penggambaran pribadi dengan berdasarkan pengamatan terhadap data-data yang diperoleh dari hasil perencanaan dan uji model fisik di laboratorium.

Penurunan dasar saluran datar dilakukan dengan menurunkan dasar saluran datar setinggi $5 \mathrm{~cm}, 10 \mathrm{~cm}, 15 \mathrm{~cm}, 20 \mathrm{~cm}$ dan $25 \mathrm{~cm}$ dari Seri Original sehingga diperoleh Seri I dengan penurunan $5 \mathrm{~cm}$ dari Seri Original, Seri II dengan penurunan $10 \mathrm{~cm}$ dari Seri Original, Seri III dengan penurunan $15 \mathrm{~cm}$ dari Seri Original, Seri IV dengan penurunan $20 \mathrm{~cm}$ dari Seri Original dan Seri V dengan penurunan $25 \mathrm{~cm}$ dari Seri Original.

Penurunan juga dilakukan pada dasar kolam olak datar dengan menurunkan dasar kolam olak datar setinggi $5 \mathrm{~cm}, 10 \mathrm{~cm}, 15 \mathrm{~cm}, 20 \mathrm{~cm}$ dan $25 \mathrm{~cm}$ dari Seri Original sehingga diperoleh Seri I dengan penurunan $5 \mathrm{~cm}$ dari Seri Original, Seri II dengan penurunan 10 $\mathrm{cm}$ dari Seri Original, Seri III dengan penurunan $15 \mathrm{~cm}$ dari Seri Original, Seri IV dengan penurunan $20 \mathrm{~cm}$ dari Seri Original dan Seri V dengan penurunan $25 \mathrm{~cm}$ dari Seri Original. 


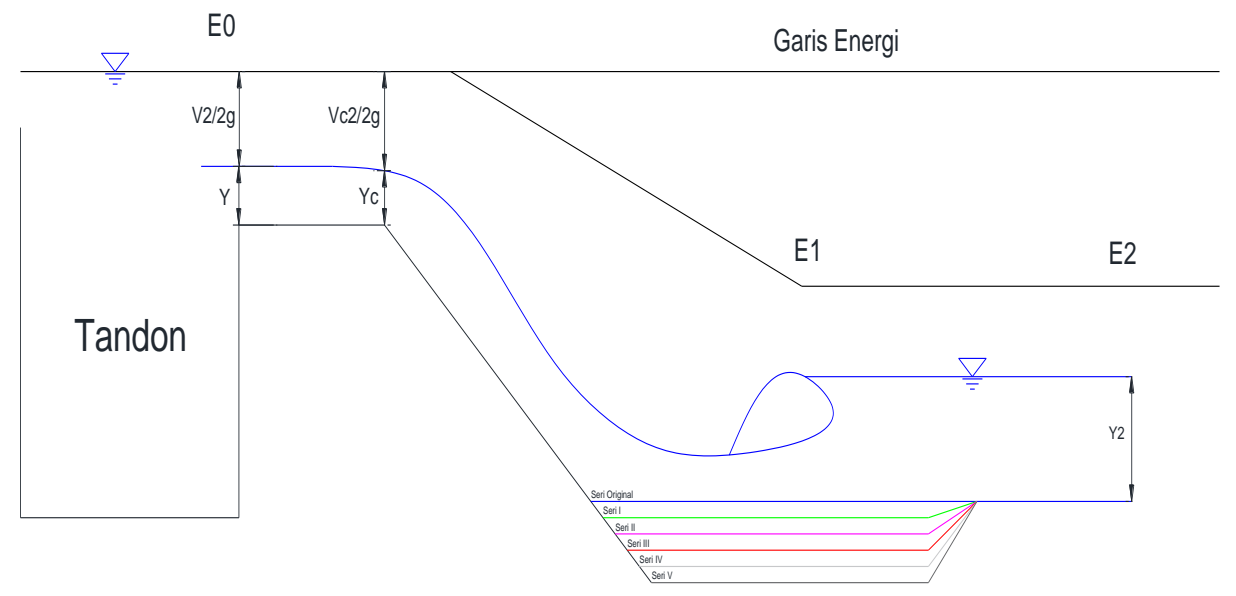

Gambar 3. Ilustrasi penurunan dasar kolam olak datar

Dua alternatif ekperimen ini dilakukan sebagai perbandingan hasil untuk mendapatkan nilai efisiensi peredaman energi terbaik. Berikut adalah pengolahan data pokok masingmasing percobaan penurunan yang ditampilkan dalam tabel di bawah ini, yaitu:

Tabel 1. Data penurunan dasar saluran datar

\begin{tabular}{|c|c|c|c|c|c|c|c|c|c|c|}
\hline Seri & $\mathrm{Q}\left(\mathrm{cm}^{3} / \mathrm{det}\right)$ & $\mathrm{Z}_{1}(\mathrm{~cm})$ & $\mathrm{Z}_{2}(\mathrm{~cm})$ & $\mathrm{Y}_{\mathrm{c}}(\mathrm{cm})$ & $\mathrm{V}_{\mathrm{c}}(\mathrm{cm})$ & $\mathrm{Y}_{1}(\mathrm{~cm})$ & $\mathrm{Vy}_{1}(\mathrm{~cm} / \mathrm{det})$ & $\mathrm{Y}_{2}(\mathrm{~cm})$ & $\mathrm{Vy}_{2}(\mathrm{~cm} / \mathrm{det})$ & $\mathrm{L}_{\mathrm{j}}(\mathrm{cm})$ \\
\hline Original & 11004 & 110 & 0 & 4,30 & 60,62 & 1,00 & 377,68 & 11,70 & 33,62 & 91 \\
\hline Seri I & 11004 & 115 & 5 & 4,20 & 58,24 & 0,95 & 373,16 & 11,25 & 33,62 & 95 \\
\hline Seri II & 11004 & 120 & 10 & 4,30 & 60,62 & 1,05 & 412,04 & 11,25 & 43,41 & 93 \\
\hline Seri III & 11004 & 125 & 15 & 4,20 & 58,24 & 1,00 & 400,21 & 11,20 & 38,83 & 105 \\
\hline Seri IV & 11004 & 130 & 20 & 4,25 & 69,99 & 1,00 & 400,68 & 11,35 & 38,83 & 88 \\
\hline Seri V & 11004 & 135 & 25 & 4,30 & 47,55 & 0,95 & 392,12 & 11,45 & 33,62 & 102 \\
\hline Original & 13109 & 110 & 0 & 4,80 & 62,15 & 1,00 & 552,50 & 12,00 & 51,36 & 96 \\
\hline Seri I & 13109 & 115 & 5 & 4,80 & 62,15 & 1,10 & 401,62 & 12,00 & 38,83 & 97 \\
\hline Seri II & 13109 & 120 & 10 & 4,75 & 67,25 & 1,00 & 420,64 & 11,95 & 47,55 & 96 \\
\hline Seri III & 13109 & 125 & 15 & 4,75 & 64,39 & 1,00 & 410,66 & 12,00 & 38,83 & 93 \\
\hline Seri IV & 13109 & 130 & 20 & 4,70 & 62,91 & 1,10 & 339,03 & 11,95 & 38,83 & 98 \\
\hline Seri V & 13109 & 135 & 25 & 4,80 & 62,15 & 1,10 & 403,26 & 12,00 & 41,18 & 108 \\
\hline Original & 15102 & 110 & 0 & 5,20 & 67,25 & 1,10 & 409,29 & 12,90 & 41,18 & 137 \\
\hline Seri I & 15102 & 115 & 5 & 5,30 & 65,83 & 1,15 & 425,76 & 12,80 & 43,41 & 105 \\
\hline Seri II & 15102 & 120 & 10 & 5,30 & 69,32 & 1,10 & 437,54 & 12,60 & 53,16 & 107 \\
\hline Seri III & 15102 & 125 & 15 & 5,30 & 65,83 & 1,15 & 413,64 & 12,25 & 51,36 & 102 \\
\hline Seri IV & 15102 & 130 & 20 & 5,25 & 86,27 & 1,10 & 419,74 & 12,65 & 47,55 & 103 \\
\hline Seri V & 15102 & 135 & 25 & 5,35 & 73,28 & 1,10 & 419,52 & 12,90 & 47,55 & 113 \\
\hline Original & 17246 & 110 & 0 & 5,65 & 71,98 & 1,20 & 419,52 & 15,00 & 45,53 & 103 \\
\hline Seri I & 17246 & 115 & 5 & 5,65 & 67,95 & 1,30 & 443,75 & 14,65 & 47,55 & 112 \\
\hline Seri II & 17246 & 120 & 10 & 5,80 & 75,19 & 1,30 & 445,02 & 14,70 & 45,53 & 107 \\
\hline Seri III & 17246 & 125 & 15 & 5,75 & 77,65 & 1,25 & 434,95 & 14,45 & 53,16 & 102 \\
\hline Seri IV & 17246 & 130 & 20 & 5,70 & 90,01 & 1,25 & 428,19 & 14,20 & 49,49 & 95 \\
\hline Seri V & 17246 & 135 & 25 & 5,75 & 83,50 & 1,25 & 440,55 & 13,50 & 67,25 & 117 \\
\hline Original & 19446 & 110 & 0 & 6,15 & 78,86 & 1,40 & 441,83 & 14,90 & 58,42 & 112 \\
\hline Seri I & 19446 & 115 & 5 & 6,30 & 74,56 & 1,25 & 455,27 & 15,15 & 54,91 & 108 \\
\hline Seri II & 19446 & 120 & 10 & 6,30 & 85,17 & 1,40 & 455,89 & 14,70 & 59,83 & 96 \\
\hline Seri III & 19446 & 125 & 15 & 6,20 & 79,45 & 1,40 & 443,96 & 15,20 & 56,60 & 106 \\
\hline Seri IV & 19446 & 130 & 20 & 6,20 & 92,59 & 1,35 & 439,69 & 15,15 & 62,91 & 112 \\
\hline Seri V & 19446 & 135 & 25 & 6,30 & 91,57 & 1,35 & 449,65 & 11,45 & 104,54 & 82 \\
\hline
\end{tabular}

Data hidrolika aliran pada Tabel 1 didapat melalui pengukuran dan perhitungan. Eksperimen penurunan berdampak pada perubahan kondisi hidrolika aliran yang berubah 
sebagaimana ditampilkan dalam tabel diketahui bahwa nilai hidrolika aliran cenderung meningkat seiring penurunan dasar saluran datar yang semakin dalam. Misal pada aliran debit $15102 \mathrm{~cm}^{3} /$ det, pada Seri Original hidrolika aliran meningkat dengan $\mathrm{VY}_{1}$ sebesar $409,29 \mathrm{~cm} /$ det pada Seri Original meningkat menjadi 419,52 cm/det pada Seri V dan VY 2 sebesar 41,18 cm/det pada Seri Original meningkat menjadi 47,55 cm/det pada Seri V.

Tabel 2. Data penurunan dasar kolam olak datar

\begin{tabular}{|c|c|c|c|c|c|c|c|c|c|c|}
\hline Seri & $\mathrm{Q}\left(\mathrm{cm}^{3} / \mathrm{det}\right)$ & $\mathrm{Z}_{1}(\mathrm{~cm})$ & $\mathrm{Z}_{2}(\mathrm{~cm})$ & $\mathrm{Y}_{\mathrm{c}}(\mathrm{cm})$ & $\mathrm{V}_{\mathrm{c}}(\mathrm{cm})$ & $\mathrm{Y}_{1}(\mathrm{~cm})$ & $\mathrm{Vy}_{1}(\mathrm{~cm} / \mathrm{det})$ & $\mathrm{Y}_{2}(\mathrm{~cm})$ & $\mathrm{Vy}_{2}(\mathrm{~cm} / \mathrm{det})$ & $\mathrm{L}_{\mathrm{j}}(\mathrm{cm})$ \\
\hline Original & 11004 & 110 & 0 & 4,30 & 60,62 & 0,90 & 321,34 & 11,55 & 11,70 & 91 \\
\hline Seri I & 11004 & 115 & 5 & 4,20 & 58,24 & 0,95 & 373,16 & 11,80 & 33,62 & 71 \\
\hline Seri II & 11004 & 120 & 10 & 4,30 & 60,62 & 17,40 & 181,59 & 11,50 & 27,45 & 63 \\
\hline Seri III & 11004 & 125 & 15 & 4,20 & 58,24 & 24,40 & 85,73 & 11,90 & 30,69 & 66 \\
\hline Seri IV & 11004 & 130 & 20 & 4,25 & 69,99 & 29,20 & 71,33 & 11,60 & 27,45 & 90 \\
\hline Seri $\mathrm{V}$ & 11004 & 135 & 25 & 4,30 & 47,55 & 34,60 & 67,25 & 11,65 & 30,69 & 104 \\
\hline Original & 13109 & 110 & 0 & 4,80 & 62,15 & 1,03 & 390,68 & 12,00 & 36,32 & 96 \\
\hline Seri I & 13109 & 115 & 5 & 4,80 & 62,15 & 1,00 & 359,53 & 12,30 & 47,55 & 100 \\
\hline Seri II & 13109 & 120 & 10 & 4,75 & 67,25 & 16,80 & 201,74 & 12,50 & 30,69 & 67 \\
\hline Seri III & 13109 & 125 & 15 & 4,75 & 64,39 & 23,80 & 91,05 & 13,00 & 33,62 & 86 \\
\hline Seri IV & 13109 & 130 & 20 & 4,70 & 62,91 & 28,60 & 76,43 & 12,70 & 36,32 & 88 \\
\hline Seri $\mathrm{V}$ & 13109 & 135 & 25 & 4,80 & 62,15 & 35,20 & 76,43 & 12,40 & 36,32 & 118 \\
\hline Original & 15102 & 110 & 0 & 5,20 & 67,25 & 1,10 & 409,29 & 12,90 & 41,18 & 137 \\
\hline Seri I & 15102 & 115 & 5 & 5,30 & 65,83 & 1,20 & 394,04 & 13,00 & 49,49 & 102 \\
\hline Seri II & 15102 & 120 & 10 & 5,30 & 69,32 & 15,95 & 236,17 & 13,55 & 35,00 & 63 \\
\hline Seri III & 15102 & 125 & 15 & 5,30 & 65,83 & 23,80 & 102,72 & 14,00 & 41,18 & 95 \\
\hline Seri IV & 15102 & 130 & 20 & 5,25 & 86,27 & 29,40 & 83,50 & 13,90 & 38,83 & 107 \\
\hline Seri $\mathrm{V}$ & 15102 & 135 & 25 & 5,35 & 73,28 & 35,30 & 84,62 & 13,40 & 41,18 & 1222 \\
\hline Original & 17246 & 110 & 0 & 5,65 & 71,98 & 1,20 & 419,52 & 15,00 & 45,53 & 103 \\
\hline Seri I & 17246 & 115 & 5 & 5,65 & 67,95 & 1,20 & 406,28 & 14,65 & 33,62 & 71 \\
\hline Seri II & 17246 & 120 & 10 & 5,80 & 75,19 & 1,45 & 367,82 & 15,10 & 45,53 & 66 \\
\hline Seri III & 17246 & 125 & 15 & 5,75 & 77,65 & 1,25 & 434,95 & 14,45 & 53,16 & 102 \\
\hline Seri IV & 17246 & 130 & 20 & 5,70 & 90,01 & 29,50 & 88,96 & 15,10 & 45,53 & 126 \\
\hline Seri $\mathrm{V}$ & 17246 & 135 & 25 & 5,75 & 83,50 & 35,75 & 95,10 & 14,80 & 43,41 & 132 \\
\hline Original & 19446 & 110 & 0 & 6,15 & 78,86 & 1,40 & 441,83 & 14,90 & 58,24 & 112 \\
\hline Seri I & 19446 & 115 & 5 & 6,30 & 74,56 & 1,30 & 423,98 & 15,50 & 64,39 & 80 \\
\hline Seri II & 19446 & 120 & 10 & 6,30 & 85,17 & 1,55 & 420,19 & 15,75 & 54,91 & 73 \\
\hline Seri III & 19446 & 125 & 15 & 6,20 & 79,45 & 1,40 & 443,96 & 15,20 & 56,60 & 106 \\
\hline Seri IV & 19446 & 130 & 20 & 6,20 & 92,59 & 29,10 & 96,09 & 14,90 & 47,55 & 130 \\
\hline Seri $\mathrm{V}$ & 19446 & 135 & 25 & 6,30 & 91,57 & 35,40 & 98,99 & 15,90 & 47,55 & 153 \\
\hline
\end{tabular}

Data hidrolika aliran pada Tabel 2 didapat melalui pengukuran dan perhitungan. Eksperimen penurunan berdampak pada perubahan kondisi hidrolika aliran yang berubah sebagaimana ditampilkan dalam tabel diketahui bahwa nilai hidrolika aliran cenderung menurun seiring penurunan dasar saluran datar yang semakin dalam. Misal pada aliran debit $15102 \mathrm{~cm}^{3} / \mathrm{det}$, pada Seri Original hidrolika aliran meningkat dengan $\mathrm{VY}_{1}$ sebesar $409,29 \mathrm{~cm} /$ det pada Seri Original menurun menjadi 84,62,52 cm/det pada Seri V dan VY 2 sebesar 41,18 cm/det pada Seri Original meningkat menjadi 38,83 cm/det pada Seri IV.

Setelah dilakukan pengolahan data pokok pada masing-masing eksperimen penurunan dasar saluran datar dan penurunan dasar kolam olak datar, selanjutnya data yang dimiliki diolah kembali untuk mendapatkan nilai efisiensi peredaman energi. Untuk mendapatkan nilai efisiensi peredaman energi, dilakukan perhitungan terlebih dahulu untuk mendapatkan nilai $\mathrm{E}_{0}, \mathrm{E}_{1}$ dan $\mathrm{E}_{2}$.

Perhitungan efisiensi peredaman energi antara $\mathrm{E}_{0}$ dan $\mathrm{E}_{2}$, digunakan rumus sebagai berikut

$$
\text { Ef Peredaman (antara } \left.E_{0} \text { dan } E_{2}\right)=\left(\left(E_{0}-E_{2}\right): E_{0}\right) \times 100 \%
$$


Berdasarkan rumus di atas, dengan menggunakan nilai $\mathrm{E}_{0}$ dan $\mathrm{E}_{2}$ yang didapat melalui perhitungan, didapatkan hasil efisiensi peredaman energi antara $E_{0}$ dan $E_{2}$ pada penurunan dasar saluran datar dan penurunan dasar saluran kolam olak datar yang ditampilkan dalam tabel berikut

Tabel 3. Efisiensi peredaman energi antara $E_{0}$ dan $E_{2}$ pada penurunan dasar saluran datar

\begin{tabular}{lllll}
\hline $\begin{array}{l}\text { Debit } \\
\left(\mathrm{cm}^{3} / \text { det }\right)\end{array}$ & Seri & $\begin{array}{l}\mathrm{E}_{0} \\
(\mathrm{~cm})\end{array}$ & $\begin{array}{l}\mathrm{E}_{2} \\
(\mathrm{~cm})\end{array}$ & $\begin{array}{l}\text { Ef Peredaman }(\%) \\
\text { antara } \mathrm{E}_{0} \text { dan } \mathrm{E}_{2}\end{array}$ \\
\hline 11004 & Original & 116,17 & 12,28 & 89,43 \\
11004 & Seri I & 120,93 & 11,83 & 90,22 \\
11004 & Seri II & 126,17 & 12,21 & 90,32 \\
11004 & Seri III & 130,93 & 11,97 & 90,86 \\
11004 & Seri IV & 136,75 & 12,12 & 91,14 \\
11004 & Seri V & 140,45 & 12,03 & 91,44 \\
13019 & Original & 116,77 & 13,34 & 88,57 \\
13019 & Seri I & 121,77 & 12,77 & 89,51 \\
13019 & Seri II & 127,05 & 13,10 & 89,69 \\
13019 & Seri III & 131,86 & 12,77 & 90,32 \\
13019 & Seri IV & 136,72 & 12,72 & 90,70 \\
13019 & Seri V & 141,77 & 12,86 & 90,93 \\
15102 & Original & 117,50 & 13,76 & 88,29 \\
15102 & Seri I & 122,52 & 13,76 & 88,77 \\
15102 & Seri II & 127,75 & 14,04 & 89,01 \\
15102 & Seri III & 132,51 & 13,59 & 89,74 \\
15102 & Seri IV & 139,04 & 13,80 & 90,07 \\
15102 & Seri V & 143,09 & 14,05 & 90,18 \\
17246 & Original & 118,29 & 16,06 & 86,43 \\
17246 & Seri I & 123,00 & 15,80 & 87,15 \\
17246 & Seri II & 128,68 & 15,76 & 87,76 \\
17246 & Seri III & 133,82 & 15,89 & 88,13 \\
17246 & Seri IV & 139,83 & 15,45 & 88,95 \\
17246 & Seri V & 144,30 & 15,80 & 89,05 \\
19446 & Original & 119,32 & 16,63 & 86,06 \\
19446 & Seri I & 124,13 & 16,69 & 86,56 \\
19446 & Seri II & 130,00 & 16,52 & 87,29 \\
19446 & Seri III & 134,42 & 16,83 & 87,48 \\
19446 & Seri IV & 140,57 & 17,17 & 87,79 \\
19446 & Seri V & 145,57 & 17,02 & 88,31 \\
\hline & & & &
\end{tabular}

Efisiensi peredaman energi antara $\mathrm{E}_{0}$ dan $\mathrm{E}_{2}$ merupakan perubahan energi yang terjadi pada energi di hulu dengan energi yang terjadi di hilir pelimpah. Persentase efisiensi peredaman energi yang tinggi menunjukan perubahan energi yang besar, sehingga penurunan dasar saluran dikategorikan berhasil apabila terjadi peningkatan persentase efisiensi peredaman energi. Sebagai contoh pada aliran debit $15102 \mathrm{~cm} 3 / \mathrm{det}$, nilai efisiensi peredaman energi antara $\mathrm{E}_{0}$ dan $\mathrm{E}_{2}$ pada Seri Original adalah $88,29 \%$, mengalami peningkatan setelah dilakukan penurunan dasar saluran datar menjadi $90,18 \%$ pada Seri V. Peningkatan ini terjadi sebab adanya perubahan energi yang besar antara energi di hulu dengan energi di hilir pelimpah. 
Tabel 4. Efisiensi peredaman energi antara $E_{0}$ dan $E_{2}$ pada penurunan dasar saluran datar

\begin{tabular}{lllll}
\hline $\begin{array}{l}\text { Debit } \\
\left(\mathrm{cm}^{3} / \text { det }\right)\end{array}$ & Seri & $\begin{array}{l}\mathrm{E}_{0} \\
(\mathrm{~cm})\end{array}$ & $\begin{array}{l}\mathrm{E}_{2} \\
(\mathrm{~cm})\end{array}$ & $\begin{array}{l}\text { Ef Peredaman }(\%) \\
\text { antara } \mathrm{E}_{0} \text { dan } \mathrm{E}_{2}\end{array}$ \\
\hline 11004 & Original & 116,17 & 11,62 & 90,00 \\
11004 & Seri I & 120,93 & 12,38 & 89,77 \\
11004 & Seri II & 126,17 & 11,88 & 90,58 \\
11004 & Seri III & 130,93 & 12,38 & 90,54 \\
11004 & Seri IV & 136,75 & 11,98 & 91,24 \\
11004 & Seri V & 140,45 & 12,13 & 91,36 \\
13019 & Original & 116,77 & 12.67 & 89,15 \\
13019 & Seri I & 121,77 & 13,45 & 88,95 \\
13019 & Seri II & 127,05 & 12,98 & 89,78 \\
13019 & Seri III & 131,86 & 13,58 & 89,70 \\
13019 & Seri IV & 136,72 & 13,37 & 90,22 \\
13019 & Seri V & 141,77 & 13,07 & 90,78 \\
15102 & Original & 117,50 & 13,76 & 88,29 \\
15102 & Seri I & 122,52 & 14,25 & 88,37 \\
15102 & Seri II & 127,75 & 14,17 & 88,90 \\
15102 & Seri III & 132,51 & 14,86 & 88,78 \\
15102 & Seri IV & 139,04 & 14,67 & 89,45 \\
15102 & Seri V & 143,09 & 14,26 & 90,03 \\
17246 & Original & 118,29 & 16,06 & 86,43 \\
17246 & Seri I & 123,00 & 15,23 & 87,62 \\
17246 & Seri II & 128,68 & 16,16 & 87,44 \\
17246 & Seri III & 133,82 & 15,89 & 88,13 \\
17246 & Seri IV & 139,83 & 16,16 & 88,45 \\
17246 & Seri V & 144,30 & 15,76 & 89,08 \\
19446 & Original & 119,32 & 16,63 & 86,06 \\
19446 & Seri I & 124,13 & 17,61 & 85,81 \\
19446 & Seri II & 130,00 & 17,29 & 86,70 \\
19446 & Seri III & 134,42 & 16,83 & 87,48 \\
19446 & Seri IV & 140,57 & 16,05 & 88,58 \\
19446 & Seri V & 145,57 & 17,05 & 88,29 \\
\hline & & & &
\end{tabular}

Berdasarkan Tabel perhitungan di atas, presentase efisiensi peredaman energi antara $\mathrm{E}_{0}$ dan $\mathrm{E}_{2}$ pada penurunan dasar kolam olak datar mengalami peningkatan. Sebagai contoh pada aliran debit $15102 \mathrm{~cm} 3 /$ det, nilai efisiensi peredaman energi antara $E_{0}$ dan $E_{2}$ pada Seri Original adalah $88,29 \%$, mengalami peningkatan setelah dilakukan penurunan dasar saluran datar menjadi 90,03\% pada Seri V. Peningkatan ini terjadi sebab adanya perubahan energi yang besar antara energi di hulu dengan energi di hilir pelimpah.

Dengan melakukan pengamatan pada Tabel 3 dan Tabel 4, secara menyeluruh eksperimen penurunan dasar saluran datar dan penurunan dasar kolam olak datar menghasilkan peningkatan presentase efisiensi peredaman energi antara $E_{0}$ dan $E_{2}$. Presentase terbaik dari efisiensi peredaman energi antara $E_{0}$ dan $E_{2}$ terdapat pada seri paling bawah yaitu Seri V.

Pada eksperimen penurunan dasar saluran datar, presentase terbaik dari efisiensi peredaman energi antara $E_{0}$ dan $E_{2}$ terjadi pada Seri $V$ dengan nilai $91,44 \%$ terjadi pada aliran debit $11004 \mathrm{~cm}^{3} /$ det. Sedangkan pada eksperimen penurunan dasar kolam olak datar, presentase terbaik dari efisiensi peredaman energi antara $E_{0}$ dan $E_{2}$ terjadi pada Seri V dengan nilai $91,36 \%$ terjadi pada aliran debit $11004 \mathrm{~cm} 3 /$ det. 


\section{Kesimpulan}

Dari hasil perhitungan dan analisa yang dilakukan terhadap ekperimen penurunan dasar saluran datar dan penurunan dasar kolam olak datar disimpulkan bahwa pada kondisi awal, hidrolika aliran mengalami peningkatan dan presentase kemampuan peredaman energi mengalami penurunan yang terjadi akibat percobaan debit mengalir yang semakin besar. Setelah dilakukan eksperimen penurunan dasar saluran datar dan penurunan dasar kolam olak datar, hidrolika aliran cenderung meningkat terjadi pada semua percobaan debit mengalir di semua seri penilitian sedangkan presentase kemampuan peredaman energi mengalami peningkatan terjadi pada semua percobaan debit mengalir di semua seri penelitian.

\section{Ucapan Terima Kasih}

Ucapan terima kasih disampaikan kepada Bapak Dr. Syaiful Anam, ST., MT. yang telah mengijinkan penulis menggunakan data uji model fisik yang dilakukan di Laboratorium Rawa dan Sungai Teknik Pengairan Universitas Brawijaya dan kepada Gloria Dihan Utomo, ST yang telah memberikan informasi dan data terkait penelitian ini.

\section{Daftar Pustaka}

[1] V. T. Chow, Hidrolika Saluran Terbuka, terjemahan E.V Nensi Rosalina. Jakarta: Erlangga, 1997

[2] Departmen Pekerjaan Umum, Standar Perencanaan Irigasi KP-01 s/d KP-07, Jakarta: Badan Penerbit Pekerjaan Umum, 2010

[3] S. K. Garg, Irrigation Engineering and Hydraulic Structures, New Delhi: Khana Publishres, 1981

[4] S. K. Mazumder, Irrigation Engineering, New Delhi: Tata McGraw-Hill Publishing Company Limited, 1983

[5] K. G. Raju, Aliran Melalui Saluran Terbuka, terjemahan Y. P. Pangaribuan, Jakarta: Erlangga, 1986

[6] S. Sosrodarsono and K. Tekeda, Bendungan Type Urugan, Jakarta: Erlangga, 2002

[7] Sub Direktorat Perencanaan Teknis, Pedoman dan Kriteria Perencanaan Teknis Irigasi, Jakarta: Direktorat Pekerjaan Umum.

[8] Sudjawadi, Teori dan Praktek Irigasi, Yogyakarta: PAU Ilmu Teknik UGM, 1989

[9] J. Peterka, Hydraulic Design of Stilling Basins and Energy Dissipator, Colorado: United States Department of the Interior, 1984

[10] B. Triatmodjo, Hidrolika II, Yogyakarta: Beta Offset, 1996 